OCCASIONAL PAPERS

ON ISLANDS AND SMALL STATES

ISSN 1024-6282

Number: 2019/02

\title{
TRADE OPENNESS, VOLATILITY AND GOVERNANCE
}

\section{Lino Briguglio and Melchior Vella}




\title{
Trade Openness, Volatility and Governance
}

\section{Lino Briguglio and Melchior Vella}

\begin{abstract}
The paper tests and confirms the hypothesis that trade openness tends to generate GDP growth volatility, and that such growth volatility is mitigated by good economic and political governance. This may explain why some economies do not exhibit a high degree of GDP growth volatility even though they are highly-open. The main implication of these results is that countries that are highly dependent on international trade, including most small states, would be exposed to GDP growth volatility, which has various downsides, as explained in the literature review. However, it does not necessary follow that highly trade-open economies small states in particular - are the ones that experience the highest degree of GDP growth volatility, if these countries adopt appropriate policies to attenuate the effect of openness on volatility.
\end{abstract}

\section{Introduction}

It is generally acknowledged that a high degree of trade openness renders a country susceptible to external economic conditions and, as a result, also be highly exposed to external shocks, possibly leading to GDP growth volatility in the country in question. This chapter will test this hypothesis, subject to a number of control variables, notably political and economic governance. The approach used to test this relationship is the regression method, using panel data.

The confirmation of the hypothesis of this study may help to explain the so-called "small state paradox" referred to in Briguglio et al. (2009), meaning that highly-open economies can and do remain relatively stable in spite of the fact that openness, by itself, tends to generate a high degree of volatility, which is often considered to be economically harmful.

This proposed relationship is an extension of the arguments put forward by Briguglio et al. (2009) and Briguglio (2016), where factors that lead to economic vulnerability were juxtaposed against factors that lead to economic resilience in order to assess the risk of a country being harmed by external shocks. These two studies were not based on regression analysis, but on observations of variables that where assumed to lead to economic vulnerability and resilience, and this analysis enabled the authors to classify countries, in terms of the so-called vulnerability and resilience $(\mathrm{V} \& \mathrm{R})$ framework.

The possibility that GDP growth volatility is influenced by economic and political governance, may also help to explain why some highly-open economies do not exhibit a high degree of GDP growth volatility, while economies which are not highly open to trade exhibit a high degree of volatility - the reason being that good economic, political and social governance may be conducive to the reduction of volatility. 
The chapter proceeds as follows. Section 2 presents a brief literature review on the relationship between trade openness and GDP growth volatility. Section 3 explains the methodology utilised in this study to test the relationship between trade openness and GDP growth volatility. Section 4 presents the estimation results and reports on some diagnostic tests relating to the validity of the results. Section 5 concludes the study and puts forward a number of implications that are derived from the results presented in the previous section.

\section{Literature Review}

\section{Openness and economic volatility}

Trade openness is often thought to bring real benefits, including improved productivity due to scale-efficiency and enhanced variety of goods at lower cost to consumers. In addition, producers would have a large market for their products, thus earning more than if the same products were sold only on the domestic market (Jensen, 2004). In this sense, it may be argued that trade openness is conducive to economic growth, ceteris paribus.

However, trade openness could also generate volatility which may harm growth. Many authors associate openness with volatility, including Karras and Song (1996), Easterly et al. (2001), Di Giovanni and Levchenko (2009), Loayza and Raddatz (2007) and Krishna and Levchenko (2009). Easterly and Kraay (2000) further argue that in small economies, characterised by high degree of openness, the positive and negative effects of openness may offset each other.

Some authors consider that export concentration exacerbates the effect on trade openness on volatility. This view is echoed by Haddad et al. (2010) who argue that export diversification (the obverse of concentration), both across products and markets, reduces growth volatility. The authors first discuss the mechanisms by which trade openness affects growth volatility, with one of the variables considered being export diversification index. They found evidence that export diversification reduces the effect of trade openness on growth volatility.

Jensen (2004) further argues that the effect of openness on volatility increases if exports are concentrated in certain commodities, including oil, which are characterised by high price fluctuations. A similar view is also expressed in Koren and Tenreyro (2007), who assert that volatility is particularly intense when exports consist mainly of commodities, a characteristic of many developing countries.

Various authors, while admitting that trade openness leads to GDP growth volatility, also acknowledge the importance of domestic factors in attenuating or exacerbating volatility, including governance, institutional frameworks and domestic economic policy. Political institutions and policy mismanagement are also likely to affect the degree to which trade openness generates volatility (Gavin and Hausmann, 1996; Acemoglu et al., 2003; Chang et al., 2009; Ahmed, 2003; Malik and Temple, 2009; Fatás and Mihov, 2013).

The extent to which trade openness affects volatility is also thought to depend on the stage of development. For example, Abubaker (2015) found that trade openness has a more sizeable effect on volatility in developing countries when compared to developed countries. In the same 
vein, Jensen (2004) contends that GDP per capita has a significant effect on income volatility. This may explain why particularly poor economies, like Least Developed Countries (LDCs), are also characterised by high income volatility, even though they do not tend to be characterised by particularly high levels of openness.

Some studies also distinguish between different types of trade openness, arguing that some forms of openness are highly destabilising compared to other forms. For example, Jackman (2014) investigated the relationship between tourism specialisation and output volatility in a sample of 34 small island developing states (SIDS). The conclusion is that there appears to be a positive relationship between tourism and output volatility, and that the impact of tourism on economic volatility depends greatly on the volatility of tourism inflows.

Financial depth is also expected to affect macroeconomic volatility. Dabla-Norris and Srivasal (2013) examine this relationship and find that financial depth could lead to a dampening of output volatility, but only up to a point. They find that at very high levels, such as those observed in many advanced economies, financial depth amplifies volatility. ${ }^{1}$

A number of studies do not confirm the positive effects of trade openness on volatility. A case in point is Cavallo (2008) who presents empirical evidence that suggests that, after appropriately accounting for the likely endogeneity of trade, the net effect of trade openness on output volatility is stabilising. This view is echoed in Cavallo and Frankel (2008).

In the same vein, Bowdler and Malik (2017) argue that trade openness can reduce volatility by shifting consumption and production towards goods for which the terms of trade are relatively stable. Likewise, Hegerty (2014) concludes that trade openness appears to be correlated with a reduction in output volatility for LDCs. Bejan (2006) argues that if one controls for government size and some measures of external risk, such as export concentration index, the effect of openness on the output volatility turns out to be negative.

\section{Openness and economic growth}

Although, most studies conclude that trade openness generates GDP growth volatility, which is a downside, openness is generally found to be positively related to GDP growth. Studies that associate openness with growth often base their arguments on the possibility that international trade stimulates competitiveness, leading to increased productivity and innovation, improves resource allocation and lowers prices for consumers. Such an argument is proposed by Winters (2004) and Easterly and Kraay (2000). Some studies show that the positive effect of trade openness on economic growth, is particularly possible when there are conducive institutional frameworks (Dollar and Kraay, 2003).

Many studies show that the quality of institutions is an important consideration in assessing the effects of trade openness. Calderon and Fuentes (2006), for example, argue that countries with strong institutions receive the largest benefit of trade openness.

\footnotetext{
${ }^{1}$ On this matter see also Tornell et al. (2003).
} 
Some authors, however, refer to the downside of trade openness on growth in the short run, due to adjustment costs of trade openness, possibly leading to poverty and inequality (Goldberg and Pavcnik, 2004).

Yanikkaya (2003), goes as far as to show that openness may actually not be good for growth. The author shows through his estimation that trade barriers are positively and significantly associated with growth, especially for developing countries.

\section{The downsides of volatility}

The arguments derived from the literature so far generally point out that while openness may be good for growth, with a few dissenting opinions, it also has negative effects by generating volatility, again with a few dissenting voices. This leads to the question as to why volatility is undesirable.

There are various reasons for this, including that fluctuations can generate a welfare loss (Loayza et al., 2007) through the negative effect of uncertainty (economic, political, and policy-related). This matter is also discussed in Montalbano (2011).

In addition, volatility may usher in a higher risk of policy failure (Gavin and Hausmann, 1996; Rodrik, 1999; Fatás and Mihov, 2013), including fiscal and monetary policies that intensify rather than calm the trade cycle. Furthermore, volatility may also lead to lower growth (Ramey and Ramey, 1995), particularly in the case of poor countries (Easterly et al., 2000). Hnatkovska and Loayza (2005) for example, estimate that a one standard-deviation increase in macroeconomic volatility results in an average loss of 1.3 percentage points in annual per capita GDP growth.

Output volatility is also associated with socially undesirable outcomes like inequality and poverty. Meschi and Vivarelli (2007) find that trade of developing countries with high income countries are destabilising as they worsen income distribution in these countries, both through imports and exports. This would seem to suggest that technological differentials between trading partners are important factors in explaining the effects of volatility that result from economic openness.

On the other side of the coin, Kose et al. (2004) found that trade openness appears to attenuate the negative relationship between growth and volatility. Specifically, they find that the estimated coefficients on interactions between volatility and trade integration are significantly positive, suggesting that countries that are more open to trade appear to be able to tolerate higher volatility without hurting their long-term growth.

García-Herrero and Vilarrubia (2006) building upon the study by Ramey and Ramey (1995), namely that volatility reduces economic growth, showed empirically that a moderate degree of volatility can be growth-enhancing, while very high volatility is clearly detrimental. These results point to the existence of a "Kuznets curve" type of relationship between volatility and growth. 


\section{Methodology}

\section{Testing the relationship between volatility and trade openness}

In the literature, the procedure used to estimate the relationship between openness and volatility is generally the regression method, often utilising panel data. GDP growth volatility is generally measured by the standard deviation of GDP growth, ${ }^{2}$ and openness is computed as the average of exports and imports, as a ratio of GDP (e.g. Hadded et. al., 2010).

The control variables utilised in the regression equations varied, as indicated in the literature review, and included variables representing policy and institutional frameworks, the stage of development, export concentration, terms of trade, financial liberalisation, and geographical dummy variables. Some of these control variables are related to each other, and in our estimation procedure we try to avoid this problem.

To test the hypothesis that trade openness generates GDP growth volatility, we specify the following equation, using annual data for 171 countries spanning the years from 2010 to 2015:

$\mathrm{VLT}_{\mathrm{i}, \mathrm{t}}=\alpha+\mathrm{b} \mathrm{OPN}_{\mathrm{i}, \mathrm{t}}+\mathrm{c} \mathrm{EGV}_{\mathrm{i}, \mathrm{t}}+\mathrm{dPGV}_{\mathrm{i}, \mathrm{t}}+\varepsilon_{\mathrm{i}, \mathrm{t}}$

where:

VLT refers GDP growth volatility; OPN refers to trade openness; EGV refers to economic governance; and PGV refers to political governance. The political governance variable also possibly captures the stage of development, given that these two variables are highly positively correlated. The subscripts indicate that all variables refer to country $i$ in year $t$. Further, $\varepsilon_{\mathrm{i}, \mathrm{t}}$ is assumed to be normally distributed with mean zero and constant variance.

The basic assumption underpinning the above equation is that GDP volatility is influenced by trade openness as well as by economic and political governance. A priori, one expects that trade openness (OPN) has a positive effect on growth volatility. On the other hand, good economic governance (EGV) and good political governance (PGV) are expected to have a negative effect on volatility, in that good governance could attenuate the effect of trade openness. Conversely, bad governance could exacerbate the effect of trade openness on volatility.

In present study, the use of fixed effects in panel data procedure was preferred over the random effects estimator. In the equation we assume that $\varepsilon_{\mathrm{i}, \mathrm{t}}$ includes a time-invariant component that captures those country-specific and time-invariant factors that are not otherwise captured by the other observable explanatory variables.

Based on the specifications outlined above, the model is fitted using fixed effects. The estimation is done using Driscoll and Kraay (1998) standard errors which produces heteroscedasticity and

\footnotetext{
${ }^{2}$ Various other methods of measuring volatility have been proposed (see Cariolle, 2012).
} 
autocorrelation consistent standard errors that are also robust to the general form of spatial dependence. Such procedure was adopted after conducting the Pesaran (2004) test which rejected cross-sectional independence

The methodology is subject to caveats which need to be acknowledged. First, the Driscoll-Kraay standard errors estimation is based on an asymptotic theory. In interpreting the results, cautiousness is advised since the panel used in this study contains a large cross-section of countries but a short time dimension. Second, the methodology is based on a static model which restricts inertia effects. The model could be improved by considering a dynamic panel data model, however, due to data constraints for some variables we rest on the Driscoll-Kraay estimator.

In addition there is the possibility that governance may be endogenous, with the ensuing estimation bias that this may create, in that countries that are more prone to shocks may be compelled to improve their governance in order to reduce exposure to shocks.

\section{Data Used}

VLT is measured by the standard deviation of GDP growth rates, with a rolling window size of 10 years. The data was sourced from the IMF economic outlook database. ${ }^{3}$

OPN is measured as the average of imports and exports of goods and services as a ratio of GDP [(Exports + Imports)/2] /GDP). The data was sourced from the UNCTAD statistics. ${ }^{4}$

PGV is measured by the Rule of Law indicator of the so-called Kaufman Index, ${ }^{5}$ which ranges between -2.5 and +2.5 . Negative values are considered as bad political governance, with higher negative values representing higher levels of bad governance, while positive values are considered as indicators of good governance, with higher positive values representing high levels of good governance. Without good governance in place, it would be relatively easy for adverse shocks to result in economic and social chaos and unrest. Thus the term for the PGV will represent an intensification effect on volatility when it takes a negative value, and an attenuation effect on volatility when it takes a positive value, given that its estimated coefficient is negative.

EGV (economic governance) is measured in two alternative ways. First, this variable is measured solely by the debt as a ratio of GDP. Second, we consider the average of the following two indices, namely (i) debt as a ratio of GDP and (ii) current account imbalances as a ratio of GDP. Following Briguglio et al. (2009) and Briguglio (2016), these indicators were chosen because they were thought to be policy induced and are therefore closely related to economic governance. It should be noted here that economic governance is likely to be the result of many other factors for which data is sparse (such as the unemployment rate, particularly in the case of small states) or which are difficult to capture quantitatively.

The debt/GDP ratio is thought to be related to economic governance, with high debt ratios

\footnotetext{
${ }_{3}^{3}$ Source: http://www.imf.org/external/pubs/ft/weo/2016/01/weodata/index.aspx

${ }^{4}$ Source: $\underline{\text { http://unctadstat.unctad.org/wds/ReportFolders/reportFolders.aspx }}$

${ }^{5}$ Sourced from: http://info.worldbank.org/governance/wgi/index.aspx\#home.
} 
indicating weak governance in this regard. Low debt ratios would allow room for manoeuvre in taxation and expenditure in the face of adverse shocks. (Briguglio et al., 2009). A country with a high current account deficits may find it more difficult to mobilize resources in order to offset the effects of economic shocks.

The debt/GDP component was considered as representing good economic governance if its value is $60 \%$ or lower, with lower values being taken as representing improving economic governance. Conversely, ratios higher than $60 \%$ were considered as associated with bad economic governance, with higher ratios being associated with deteriorating economic governance. ${ }^{6}$ The debt/GDP ratio was rescaled so that $60 \%$ was set to equal zero, while values equal to or higher than $60 \%$ were rescaled to take values of between 0 and -0.5 and values equal to or lower than $60 \%$ were rescaled to take values of between 0 and 0.5 . This procedure of assigning negative values for weak economic governance is helpful for drawing Figure 1, as will be explained in Section 4.

The current account /GDP component was considered as being associated with good economic governance if its value was 0 or higher, with higher values representing improving economic governance. $^{7}$ Conversely, negative values of the ratio were associated with bad economic governance with higher negative ratios being associated with worse economic governance. Positive and negative values of the ratio were rescaled to take a value of between +0.5 and -0.5 . This rescaling procedure was useful in order to take an average of the debt ratio and the current account balance, since both were rescaled to take a value of between -0.5 and +0.5 , with zero being the point of neutrality. ${ }^{8}$

To separate the effects of initial cyclical factors both the debt to GDP and current account imbalances ratio are measured with a 10-year backward moving average. The data was sourced from the IMF World Economic Outlook database. ${ }^{9}$

\section{Estimation Results}

\footnotetext{
${ }^{6}$ A debt-to-GDP ratio of $60 \%$ is considered as a prudential limit for the EU member states, and a higher ratio is considered be fiscally unsustainable. However there is considerable debate on this threshold value of the Debt/GDP ratio (see Chowdhury and Islam, 2014).

${ }^{7}$ Although a current account surplus is generally considered to be a better situation than a current account deficit, one could question whether such a surplus is a sign of good economic governance, as such a situation may signify that a country could improve its standard of living, by, for example, stimulating demand and encouraging imports. In addition, a current account surplus may push up the exchange rate of a floating domestic currency. On the other hand, a current account deficit may be an indication that a country is living beyond its means, and therefore not sustainably - thus associating it with weak economic governance. In addition, a deficit reflects relatively lower national savings in relation to investment. On this issue see Ghosh and Ramakrishnan (2006).

${ }^{8}$ The cut of value of zero is somewhat arbitrary, but it will not affect the statistical significancee of the estimated coefficients. It will however be of some importance when interpreting the results, given that a value of less than zero will be interpreted as an indicator of bad economic governance, with higher negative values suggesting a higher degree of bad governance

${ }^{9}$ Source: http://www.imf.org/external/pubs/ft/weo/2016/01/weodata/index.aspx
} 
Using the available data for 171 countries, ${ }^{10}$ and using the debt/GDP to measure EGV, the following estimation results were obtained:

$\begin{array}{lcccc}\mathbf{V L T}= & \mathbf{2 . 2 4} \\ t \text {-statistics } & (6.89) & \mathbf{0 . 0 4} \text { OPN } & -\underset{(5.14)}{2.71} \mathbf{~ E G V} & -\mathbf{1 . 8 5} \text { PGV } \\ (-4.17) & (-2.93)\end{array}$

R-squared $=0.84 \quad$ Number of observations $=1,026$

The estimated parameters are in line with a priori expectations. The numbers in parentheses are the t-statistics and indicate that the estimates of the coefficient on the explanatory variables are statistically different from zero at the $95 \%$ level.

The results confirm that, keeping governance constant, trade openness does intensify GDP growth volatility. Nevertheless, this does not automatically imply that more open economies face a higher degree of growth volatility. Indeed, the regression results confirm that wellmanaged economies could mitigate the effects of openness. In addition, the stage of development, measured by GDP per capita, could also be associated with a dampening of volatility, given that GDP per capita is closely correlated to political governance.

The equation performed satisfactorily in terms of residual diagnostic tests. Pooled unit root tests were also conducted on the variables, showing that the null hypothesis of having a unit root process is not accepted at $1 \%$ level. Regarding multicollinearity, the correlation between OPN, EGV and PGV across countries was not found to be unduly high. A diagnostic test was also conducted to test for fixed effects.

The results of the Hausman test decisively favours the use of the fixed effects estimator over random effects in this analysis. This confirms the use of the fixed effects over random effects in order to account for county's unobserved heterogeneity.

We also estimated an alternative specification where the EGV variable was measured as an average of the ratios debt /GDP and current account balance/GDP. The estimated results are as follows:

$\begin{array}{lcccc}\mathbf{V L T}= & \mathbf{1 . 8 8}+ & \mathbf{0 . 0 4} \text { OPN } & -\mathbf{5 . 3 9} \text { EGV } & -\mathbf{1 . 7 9} \text { PGV } \\ t \text {-statistics } & (6.11) & (4.97) & (-1.75) & (-2.77)\end{array}$

R-squared $=0.84 \quad$ Number of observations $=1,026$

As can be seen by comparing Equation 1 with Equation 2 the results are very similar, with the only difference that the EGV variable is now only significant at the $90 \%$ level.

\footnotetext{
${ }^{10}$ The IMF database, from which the volatility data was sourced, contained 187 politically independent states. Sixteen countries were omitted due to missing data. These are Afghanistan, Chad, Eritrea, Iraq, Kiribati, Kosovo, Liberia, Marshall Islands, Mongolia, Montenegro, Palau, Sudan, Syria, Timor-Leste, Tonga, Turkmenistan
} 


\section{Implications of the results}

The results would seem to suggest that the hypothesis that GDP growth volatility is the result of trade openness and good governance is confirmed. This implies that volatility can be the result not only by high exposure to external economic conditions but also of internal governance factors. This implication is illustrated in Figure 1.

\section{Figure 1: GDP growth volatility and trade openness}

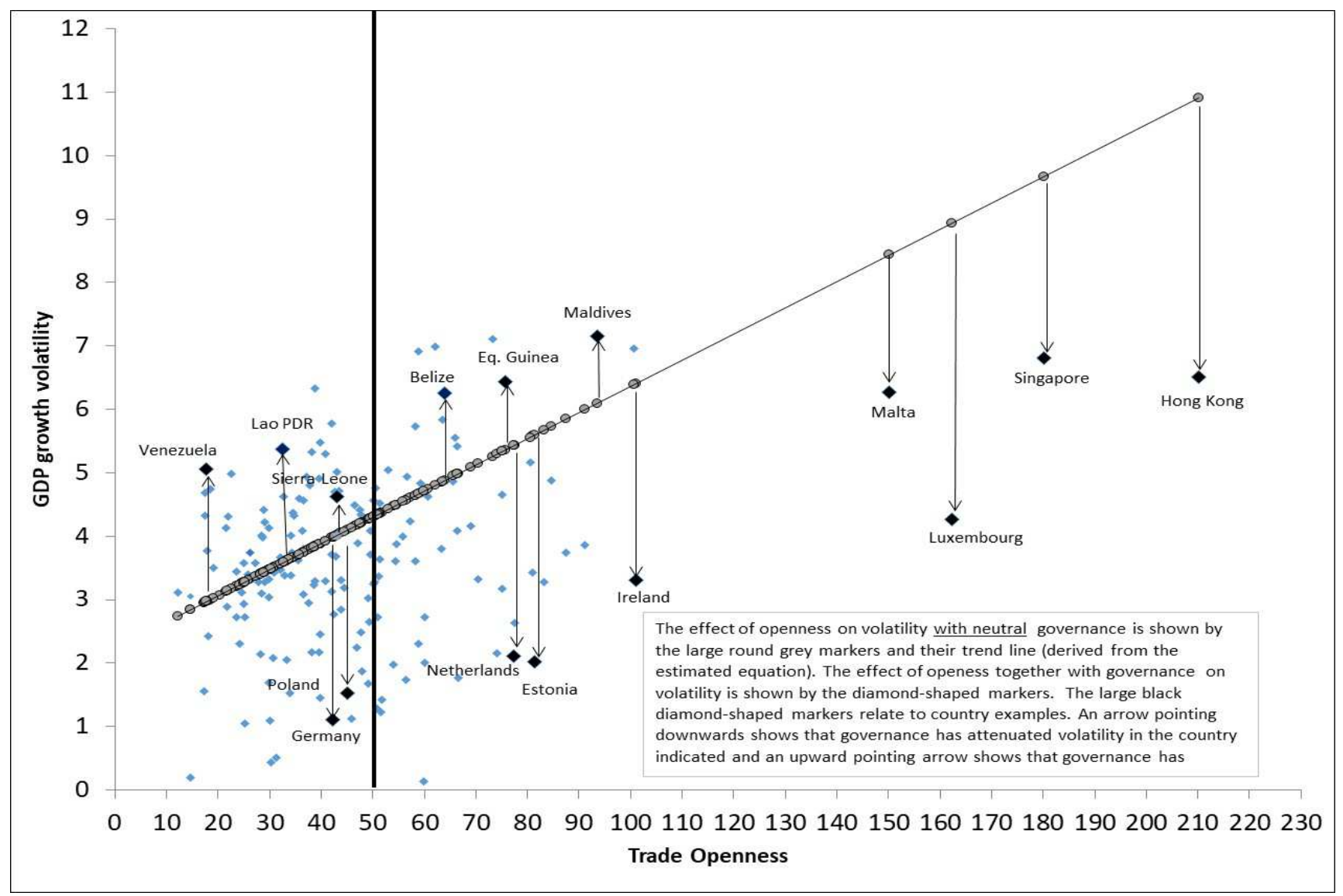

In Figure 1, GDP growth volatility is measured along the vertical axis and trade openness on the horizontal axis. The markers show volatility with and without the governance effect, utilising the estimation results of Equation $1 .{ }^{11}$ Volatility without governance is estimated by removing the governance terms from the estimated equation (shown by the large round grey markers in the diagram, with a straight line trend line) and volatility with governance is estimated by including the governance terms in the estimated equation (shown by the diamond shaped small markers in the diagram).

\footnotetext{
${ }^{11}$ Similar results were obtained when applying the results of Equation 2.
} 
From this chart we can identify four possible scenarios into which countries can be grouped, as explained below.

The right section of the diagram relates to those countries that have a relatively high degree of trade openness, in this case higher than $50 \%$. Some register a volatility score below the trend line, indicating that the governance effect has attenuated their volatility, as shown by a downward-pointing arrow. Others have a volatility score above the trend line, indicating that governance has intensified their volatility, as shown by the upward-pointing arrow. This means that the right side of the diagram has two types of economies, namely (a) highly-open economies with good governance (HOGG) which include Malta, Singapore, and Luxembourg and (b) highly-open economies with weak governance (HOWG) which include Equatorial Guinea, Maldives and Belize. ${ }^{12}$

The left section of the diagram relates to those countries that have a relatively low degree of trade openness. Again, well-governed countries register a volatility score below the trend line, while weakly-governed countries have an intensified volatility score above the trend line. This means that the left side of the diagram has two additional types of economies, namely (c) slightly-open economies (less than $50 \%$ of GDP) with good governance (SOGG), including USA, Germany and Poland and (d) slightly-open economies with weak governance (SOWG), including Venezuela, Sierra Leone and Russia.

\section{Volatility and Small States}

The economies of small states are generally characterised by a high degree of trade openness, meaning that they are likely to be highly exposed to growth volatility. Using the benchmarking exercise proposed in Figure 1, the distinction between attenuated or intensified volatility can be made. Small states with a volatility score below the trend line in Figure 1 are those that have possibly attenuated their growth volatility through good economic and political governance. Conversely, small states with a volatility score above the trend line are those that possibly exacerbated their volatility as a result of weak governance.

Table 2 provides an overview of small states in terms of their growth volatility with and without governance as measured from the estimated regression. ${ }^{13}$ Almost all of the small states in Europe are endowed with good governance scores that mitigated volatility associated with trade openness. Similarly, governance scores are also conducive to the reduction of volatility in most of the small states in the Caribbean region. By contrast, the picture is mixed in African, Atlantic/Indian and Pacific regions. Such benchmarking verifies the "small state paradox" (Briguglio et al., 2009), such that highly-open economies can and do withstand their inherent vulnerability by adopting policies that counteract growth volatility.

\footnotetext{
${ }^{12}$ It should be noted, with regard to the classification of countries discussed above, that choice of cut-off value of openness of $50 \%$ is subjective and the classification of countries would change if a different cut-off point is chosen. Irrespective of this threshold, however, this does not change our results that good governance is likely to attenuate the effect of trade openness on volatility

${ }^{13}$ Small states are defined here as sovereign countries with a population of at most 1.5 million people. This is in line with criteria adopted by the World Bank criteria (see: http://www.worldbank.org/en/country/smallstates) and the Commonwealth Secretariat (http://thecommonwealth.org/small-states).
} 
It should be recalled that governance captures the effects of political (PGV) as well as economic governance (EGV), and consequently their separate scores could reinforce or counteract each other. By way of example, Cyprus ranked amongst the weakly governed countries because its weak economic governance (high debt-to-GDP ratio and large current account deficit) more than offset the effect of the favourable political governance score. Conversely, Bahrain ranked behind Cyprus with regard to the political governance score, however, it performed very well in terms of economic governance, and that is why it was ranked among the well-governed countries.

Table 2: Small states classified by degree of openness and governance

\begin{tabular}{|l|l|}
\hline \multicolumn{1}{|c|}{ Highly-open economies with good governance } & \multicolumn{1}{c|}{ Highly-open economies with weak governance } \\
\hline $\begin{array}{l}\text { Luxembourg, Estonia, Iceland, Mauritius, Malta, } \\
\text { Tuvalu, Bahrain, Vanuatu, Saint Lucia, Micronesia } \\
\text { Suriname, Antigua and Barbuda, Lesotho, Cape Verde, } \\
\text { Solomon Islands, Guyana }\end{array}$ & $\begin{array}{l}\text { Fiji, Cyprus, Seychelles, Maldives, Equatorial Guinea, } \\
\text { Belize }\end{array}$ \\
\hline Moderately-open economies with good governance & Moderately-open economies with weak governance \\
\hline $\begin{array}{l}\text { Brunei Darussalam, Samoa, Bahamas, Barbados, Saint } \\
\text { Vincent and the Grenadines, Dominica, Swaziland, } \\
\text { Gabon, Saint Kitts and Nevis, Bhutan }\end{array}$ & $\begin{array}{l}\text { Djibouti, Grenada, Comoros, Gambia, Guinea-Bissau, } \\
\text { Sao Tome and Principe }\end{array}$ \\
\hline
\end{tabular}

\section{Conclusions and Implications}

This study has tested the relationship between trade openness and GDP growth volatility, using a sample of 171 countries. The regression equation was kept as simple as possible, reflecting the possibility that GDP growth volatility is influenced by trade openness, economic governance and political governance, the latter variable also possibly proxying the stage of development.

By keeping other relevant variables constant, this study confirms the hypothesis that trade openness exacerbates growth volatility. However, the possibility that growth volatility is mitigated by good economic and political governance is also confirmed. This may explain why some economies do not exhibit a high degree of GDP growth volatility even though they are highly-open.

The main implication of these results is that countries that are highly dependent on international trade, including most small states, would be exposed to GDP growth volatility, which has various downsides, as explained in the literature review. However, it does not necessary follow that highly trade-open economies - small states in particular - are the ones that experience the highest degree of GDP growth volatility. This is because, as our results suggest, countries may adopt appropriate policies to attenuate the effect of openness on volatility. In other words, it is possible that highly-open economies do not exhibit a high degree of GDP growth volatility, while economies which are not highly trade-open may exhibit a high degree of volatility, as a result of weak governance.

A major implication that can also be derived from this study is that highly trade-open countries, in particular small states, are those countries which mostly need to adopt good economic and political governance, if they are to counteract growth volatility, with all its downsides.

This is in line with the vulnerability/resilience framework, proposed in Briguglio et. al (2009) and Briguglio (2016), where factors that lead to economic vulnerability were juxtaposed against 
factors that lead to economic resilience in order to assess the risk of a country being harmed by external shocks. This framework was used to show that small economically vulnerable states, can, and do, adopt policies that enable them to withstand the downsides of economic vulnerability.

\section{References}

Abubaker, R. (2015). The asymmetric impact of trade openness on output volatility. Empirical Economics. 49 (3): 881-887.

Acemoglu, D., Johnson, S., Robinson, J., and Thaicharoen, Y. (2003). institutional causes, macroeconomic symptoms: volatility, crises and growth. Journal of Monetary Economics, 5 (1): 49-123

Ahmed, S. (2003). Sources of economic fluctuations in Latin America and implications for choice of exchange rate regimes. Journal of Development Economics, 72 (1): 181-202.

Bejan, M. (2006). Trade openness and output volatility. Instituto Tecnologico Autonomo de Mexico.

Bowdler, C., and Malik, A. (2017). Openness and inflation volatility: Panel data evidence. The North American. Journal of Economics and Finance, 41: 57-69.

Briguglio (2016). Exposure to external shocks and economic resilience of countries: evidence from global indicators. Journal of Economic Studies, Vol. 43 (6): 1057-1078.

Briguglio, L., Cordina, G., Farrugia, N. and Vella, S. (2009). Economic vulnerability and resilience: concepts and measurements. Oxford Development Studies, 37 (3): 229-247.

Calderon, C. and Fuentes, R. (2006). Complementarities between Institutions and Openness in Economic Development: Evidence for a Panel of Countries. Cuadernos de Economía, 43: 49-80.

Cariolle, J. (2012). Measuring macroeconomic volatility: applications to export revenue data, 1970-2005. FERDI working paper no I14. Clermont Ferrand, France: FERDI.

Cavallo, E. A. (2008). Output volatility and openness to trade: a reassessment. Economia, 9 (1): $105-138$.

Cavallo, E.A., and Frankel., J.A. (2008). Does openness to trade make countries more vulnerable to sudden stops, or less? Using gravity to establish causality. Journal of International Money and Finance, 27 (8), 1430-1452.

Chang, R., Kaltani, L., and Loayza, N. V. (2009). Openness can be good for growth: The role of policy complementarities. Journal of Development Economics, 90(1), 33-49.

Chowdhury, A. and Islam, I. (2014). Is there an optimal debt-to-GDP ratio?. VoxEU Debate on the Global Crisis, 9.

Dabla-Norris, M. E., and Srivisal, M. N. (2013). Revisiting the link between finance and macroeconomic volatility. USA: International Monetary Fund.

di Giovanni, Julian and Andrei A. Levchenko (2009). "Trade openness and volatility". Review of Economics and Statistics, 91(3) (August): 558-585.

Dollar, D., and Kraay, A. (2003). Institutions, trade, and growth. Journal of Monetary Economics, 50 (1): 133-162.

Driscoll, J. C., and Kraay, A. C. (1998). Consistent covariance matrix estimation with spatially dependent panel data. Review of economics and statistics, 80 (4), 549-560. 
Easterly, W. and Kraay, A. (2000). Small States, small problems? income, growth, and volatility in small states. World Development, 28 (11): 2013-2027.

Easterly, W., Islam, R., and Stiglitz, J. E. (2001). Shaken and stirred: explaining growth volatility. Annual World Bank conference on development economics, 2000: 191-211

Fatás, A. and Mihov, I. (2013). Policy volatility, institutions and economic growth. Review of Economics and Statistics, 45 (2): 362-376.

García-Herrero, A. and Vilarrubia, J. (2006).The Laffer curve of macroeconomic volatility and growth: can it be explained by the different nature of crises? Paper prepared by A. García-Herrero and J. Vilarrubia presented at the XI Meeting of the Network of America Central Bank Researchers hosted by Banco Central de la República Argentina, in Buenos Aires, November 22-24, 2006.

Gavin, M. and Hausmann, R. Macroeconomic (1998). Volatility and economic development. In The Political Dimension of Economic Growth. Palgrave Macmillan UK: 97-116..

Goldberg, P.J. and Pavcnik, N. (2004). Trade, inequality, and poverty: what do we know? Evidence from recent trade liberalization episodes in developing countries. NBER Working Paper 10593Growth Volatility". In Boris Pleskovic and Nicholas H. Stern (editors), Annual World Bank Conference on Development Economics: 191-211. Washington, DC: The World Bank.

Ghosh, A. and Ramakrishnan, U. (2006). Current account deficits: is there a problem? Finance and Development. 43 (4).

Hadded, M., Lim, J.J. and Saborawski, C. (2010) .Trade openness reduces growth volatility when countries are welld iversified. World Bank Policy Research Working Paper No. 5222 .

Hegerty, S. W. (2014). Openness and macroeconomic volatility: do development factors drive such ambiguous results? Department of Economics, Northeastern Illinois University

Hnatkovska, V. and Loayza, N. (2005). "Volatility and growth". In Aizenmann, J. and Pinto, B.(eds)., Managing Economic Volatility and Crises, Cambridge: Cambridge University Press.

Jackman, M. (2014). Output volatility and tourism specialization in small island developing states. Tourism Economics, 20(3): 527-544.

Jensen, M. (2004) Income volatility in small and developing economies: export concentration matters. Geneva: World Trade Organisation.

Karras, G. and Song, F. (1996). Sources of business-cycle volatility: An exploratory study on a sample of OECD countries. Journal of Macroeconomics. 18(4): 621-637

Koren, M. and Tenreyro S. (2007). Volatility and development. The Quarterly Journal of Economics, 122 (1): 243-287.

Kose, M.A., E. Prasad and M. Terrones (2004). "how do trade and financial integration affect the relationship between growth and volatility?" Washington, DC, United States: International Monetary Fund. Mimeographed document.

Krishna, P and Levchenko, A (2009). comparative advantage, complexity and volatility. NBER Working Paper No. 14965.

Loayza, N. V., Ranciere, N. and Serven, L. and Ventura, J. (2007). macroeconomic volatility and welfare in developing countries: an introduction. The World Bank Economic Review, 21(3): 343-357. 
Loayza, N.V. and Raddatz, C. (2007) The structural determinants of external vulnerability the structural determinants of external vulnerability . The World Bank Economic Review, 21 (3): $359-387$.

Malik, A. and Temple, J. (2009). The geography of output volatility. Journal of Development Economics, 90 (2): 163-178.

Meschi, E. and Vivarelli, M. (2007) Trade openness and income inequality in developing countries. Working Paper. Coventry: University of Warwick. Centre for the Study of Globalisation and Regionalisation. Working papers; No.232.

Montalbano, P.L. (2011); trade openness and developing countries' vulnerability: concepts, misconceptions, and directions for research. World Development, 39 (9): 1489-1502.

Pesaran, M. (2004). general diagnostic tests for cross section dependence in panels. Cambridge Working Papers in Economics No. 0435 Faculty of Economics, University of Cambridge.

Ramey, G., Ramey, V., (1995). Cross-country evidence on the link between volatility and growth, The American Economic Review, 85, No. 5, pp. 1138-1151

Rodrik, D. (1999). Where did all the growth go? external shocks, social conflict, and growth collapses. Journal of Economic Growth, 4 (4): 385-412.

Tornell, A., Westermann, F., Martinez, L. (2003). Liberalization, growth and financial crises: lessons from mexico and the developing world, Brookings Papers on Economic Activity No. 2

Winters, L. A. (2004). Trade liberalisation and economic performance: An overview The Economic Journal, 114: 4-F21

Yanikkaya, H. (2003). Trade openness and economic growth: a cross-country empirical investigation. Journal Of Development Economics, 72(1), 57-89. 